\title{
Charakterystyka pojęć dotyczących Afryki zawartych we współczesnych słownikach języka polskiego
}

\section{Przedmiot, główny cel i metodologia badań}

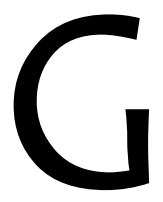
łównym przedmiotem moich badań jest dokonanie porównawczego opisu językowego obrazu Afryki i jej mieszkańców zawartego w wybranych reportażach polskich autorów. Spośród licznych tekstów tego typu wybiorę teksty współczesne, przede wszystkim te, które zostały opublikowane w gazetach. Ich całkowita liczba na obecnym etapie badań nie jest jeszcze znana, prawdopodobnie jednak będą to reportaże Adama Leszczyńskiego, Olgi Stanisławskiej, Wojciecha Tochmana, Bogdana Szczygła, Wojciecha Jagielskiego. Nie może również zabraknąć nawiązań do mistrza polskiego reportażu Ryszarda Kapuścińskiego, a także relacji Antoniego Ferdynanda Ossendowskiego i Kazimierza Nowaka.

Planuję ponadto uzyskać dostęp do tekstów suahilijskich. Tradycja opowieści z podroży jest bardzo stara w literaturze suahili, podobnie jak tradycja podróżowania. Jednak poznanie gatunku reportażu występującego w Afryce, uzyskanie dostępu do tekstów i dokonanie wyboru materiału to zadania wymagające wiele czasu i wysiłku, dlatego też na obecnym etapie nie mogę podać nazwisk autorów. Wskazane byłyby także kwerendy w bibliotekach w Afryce. Zanim jednak zacznę badać teksty podróżnicze, chciałabym dokonać analizy wybranych haseł słownikowych i leksemów występujących w obu korpusach językowych, aby porównać zawarty w nich językowy obraz Afryki, znaleźć podobieństwa i różnice w sposobach konceptualizacji rzeczywistości przez Polaków i mieszkańców Afryki Wschodniej'. Efekty przeprowadzonej przeze mnie analizy zamieszczę w rozprawie doktorskiej.

W planowanych badaniach posłużę się metodologią wywodzącą się z nurtu badań kognitywnych, czyli językowym obrazem świata [JOS], który w Polsce zapoczątkowany został przede wszystkim przez lubelski ośrodek naukowy [Bartmiński 1990, 2006]. W pierwszej części pracy doktorskiej krótko przedstawię wybraną metodologię,

\footnotetext{
1 Język suahili jest używany głównie w tej części Afryki, stąd też to ograniczenie.
} 
Relacje z badań

uwzględniając relacje języka i kultury, a także opiszę motyw Afryki w literaturze polskiej, sytuację polityczną Afryki [por.: Zins 2001], typologię reportażu [por.: Wojtak 2004, Wolny 1996]. Opisując świat człowieka, zastosuję metodologię Aleksandry Niewiary, czyli wyróżnię poszczególne domeny i dokonam ich charakterystyki [Niewiara 2000]. Z kolei świat zewnętrzny poddam kategoryzacji, posługując się wybranymi ujęciami leksykograficznymi². Następnie dokonam wyboru konkretnego materiału językowego (współczesne reportaże polskich autorów), aby w części drugiej przedstawić analizę językową tych tekstów, haseł słownikowych (polskich i suahilijskich), a także materiału zaczerpniętego z korpusów.

Analizę należy zacząć od materiału zawartego w polskich słownikach, a także w Korpusie Języka Polskiego PWN. Artykuł ten poświęcam trzem hasłom dotyczącym Czarnego Lądu: Afryka, Afrykanin, Murzyn. Przedstawione poniżej wnioski stanowią jedynie wstęp do dalszych badań. Kolejnym krokiem, już na etapie pisania rozprawy doktorskiej, będzie analiza pierwszych tekstów na podstawie metodologii Aleksandry Niewiary, a także zbadanie materiału zawartego w słownikach języka suahili.

\section{Wybór słowników i analiza konkretnych haseł}

Spośród wielu słowników wybrałam przede wszystkim pozycje współczesne, sięgnęłam jednak również do najważniejszych wcześniejszych prac, aby pokazać istotne różnice w eksplikacjach.

Definicje słownikowe powinny być wspólne użytkownikom danego języka, zwięzłe, proste i zrozumiałe. Analizę zacznę od leksemu Afryka, który uważam za jeden z podstawowych do dalszych badań. Dodać należy, że hasło to w większości słowników nie zostało wynotowane, ale wynika to z koncepcji budowy danych słowników, w których autorzy postanowili nie uwzględniać nazw geograficznych [SWJP 2003, WSJP 2006, SJP 1998, NSJP 1937, SJP 1958, USJP 2009, WSJP 2007, ISJP 2000]. Z kolei w przypadku wyrazów pochodnych od leksemu Afryka odnotowałam wysoką frekwencję takich wyrazów, jak afro, Afroamerykanin, Afrykanin, Afrykaner, afrykanizacja, afrykański itd. W kilku słownikach znajdujemy natomiast Afrykę jako wyjaśnienie innego hasła, mianowicie frazeologizmu Czarny Ląd / Czarny Kontynent, a także osobne hasło - Czarna Afryka.

2 Konkretne ujęcia leksykograficzne nie zostały jeszcze wybrane, gdyż opis świata zewnętrznego stanowi dalszy etap pracy. Prawdopodobnie pomocne okażą się dla mnie ujęcia zaprezentowane przez Dorotę Rembiszewską [Rembiszewska 2005:

37-52] i klasyfikacja tematyczna dokonana przez Andrzeja Markowskiego [Markowski 1990]. 


\section{AFRYKA}

Na początku warto poznać etymologię omawianego leksemu Afryka. W czasach Cesarstwa Rzymskiego odnosił się on do północnych obszarów dzisiejszej Afryki (stolicą ówczesnej prowincji była Kartagina). Zakres tego leksemu poszerzył się jednak i objął cały kontynent. Africa terra znaczyło po prostu Ziemia Afrów; Afrowie (łac. sing. Afer, pl. Afri) mieszkali na terenach wokół Kartaginy. Leksem Afer prawdopodobnie odnosi się do fenickiego afar, oznaczającego kurz, pył [por.: SEJP 1927, NSEJP 2003].

Poniżej prezentuję poszczególne definicje słownikowe leksemu Afryka, a także określeń pozostających w ścisłym związku z ww. leksemem (por. Czarna Afryka) oraz leksemów synonimicznych, które wystąpiły w badanym materiale.

Afryka - jedna z głównych części świata [SJP 1951]; kontynent na półkuli wschodniej po obu stronach równika [USJP 2003].

Czarna Afryka - Afryka na południe od Sahary, zamieszkała głównie przez ludność murzyńską [USJP 2003].

czarny kontynent, ląd - Afryka, szczególnie środkowa i południowa, zamieszkała przez ludzi o czarnym kolorze skóry. Wyprawa wróciła z głębi czarnego lądu [SWJP 2003].

Czarny kontynent, ląd - Afryka [USJP 2003, SF PWN 2008, WSJP 2006, SJP 1998]; kontynent, ląd zamieszkały przez Murzynów [SJP 1958]; Afryka, szczególnie środkowa i południowa, zamieszkała przez ludzi o czarnym kolorze skóry [WSJP 2007]; tradycyjne rytmy Czarnego Lądu [KJP PWN]; Czarny ląd lub Czarny kontynent to Afryka [ISJP 2000]. Według autorów tego słownika wyrażenie to występuje jednak głównie w literaturze.

Z powyższych cytowań wynika, że definicje słownikowe Afryki są zwykle bardzo ubogie i przedstawiają Afrykę jako kontynent.

Warto w tym miejscu zauważyć, że Afryka jest hiperonimem, a Czarna Afryka hiponimem. Czarna, bo zamieszkała przez ludność murzyńską, Murzynów, czyli ludzi o ciemnym (czarnym) kolorze skóry. W literaturze przedmiotowej często tę część Afryki określa się jako Afryka subsaharyjska. Jak pisze Andrzej Szyjewski: „Określenie Czarna Afryka powinno ograniczyć pole zainteresowań do tubylczej ludności murzyńskiej, tzw. negroidów, czyli czarnej odmiany człowieka. Jednak obok tej odmiany od tysiącleci żyją w Czarnej Afryce przedstawiciele trudnej do scharakteryzowania „rasy” kapoidalnej (w terminologii C.S. Coona), czyli ludności khoisańskiej (Buszmeni i Hotentoci), a i Pigmeje nie są zaliczani do negroidów właściwych, lecz do negrytów. Część plemion wschodnioafrykańskich, jak Kuszyci i Niloci, mimo czarnego koloru skóry, budową 
Relacje z badań

anatomiczną i cechami języka przynależy bardziej do białej odmiany człowieka. Madagaskar wreszcie zamieszkują Malgasze - ludność mieszana, o przeważających jednak cechach austronezyjsko-malajskich, a więc należących do żółtej odmiany człowieka" [Szyjewski 2003: 5]. Jak wynika z przytoczonej wypowiedzi, mieszkańcy Afryki są bardzo zróżnicowani, lecz powszechnie traktuje się ich jako czarnych (ciemnobrązowych, ciemniejszych, bardzo ciemnych) i podobnych do siebie, a nawet trudnych do odróżnienia. Stąd też funkcjonowanie pojęcia Czarna Afryka jako obszaru zamieszkałego tylko przez ludność czarną, murzyńską. Obok Czarnej Afryki w języku polskim pojawia się określenie przeciwstawne, czyli Biała Afryka, oznacza ono obszar zamieszkany przez ludność arabsko-berberyjską, czyli białą. Dotyczy ono terenów północnych Afryki (Sahara, Półwysep Somalijski, wybrzeże Morza Śródziemnego, wybrzeże Morza Czerwonego). Leksem Biała Afryka nie występuje jednak w słownikach języka polskiego, nie jest popularny, występuje jedynie sporadycznie, np. w Korpusie Języka Polskiego PWN (na obszarze „,białej” Afryki; rząd dążący do wydzielenia „białej” Afryki). Jest to jednak określenie słabo przyjęte, o czym świadczy także użycie w przytoczonych przykładach cudzysłowu. Warto także wspomnieć o filmie w reżyserii Claire Denis, White Material, który w Polsce tłumaczony był jako Biała Afryka. Kolejne użycia odnoszą się do literatury, tj. do tytułu tomiku poezji (Bartłomiej Majzel, Biała Afryka) i twórczości południowoafrykańskiego pisarza - Johna Maxwella Coetzee, Białe pisarstwo. O literackiej kulturze Afryki Południowej. W tych kontekstach określenie to odnosi się jednak wyłącznie do ludności białej.

W wyniku analizy definicji słownikowych otrzymujemy centralne cechy leksemu Afryka: częśś3 (czegoś - świata lub Afryki), miejsce (zamieszkania), czarny / ciemny, czarnoskóry mieszkaniec (Murzyn).

\section{AFRYKANIN}

Podstawowe rozwinięcie tego hasła to zwykle człowiek należący do rasy czarnej [USJP 2003], czasem autorzy notują odmiany [SJP 1998], a także podają synonim Murzyn [USJP 2003]. Leksem Afrykanin nie występuje jednak w wielu słownikach, za to ich autorzy często wynotowują właśnie Murzyna. W badanym materiale wielokrotnie znajdowałam także inne leksemy określające ludzi, którzy pochodzą z Afryki, np. Afroamerykanin, do Afryki przybyli i się tam osiedlili, np. Afrykaner, a także sporadycznie Afrykańczyka [USJP 2003] i Negra [SJP 1958].

3 Hiponimiczne określenia zawężające (czarna, „biała”, subsaharyjska) wskazują na „konkretne” Afryki. 
Afrykanin - mieszkaniec Afryki, zwłaszcza Murzyn [USJP 2003]; to osoba pochodząca z Afryki, zwłaszcza czarnoskóra [ISJP 2000]; Afrykanin, Afrykańczyk, Afer, Afryk, Afrykant - rodem z Afryki; Afrowie dzicy wielu chrześcijan pobrali [SJP 1951].

Afrykańczyk - zob. Afrykanin [USJP 2003].

Afroamerykanin - urz. czarnoskóry mieszkaniec Stanów Zjednoczonych; Afroamerykanka - czarnoskóra mieszkanka Stanów Zjednoczonych [USJP 2003].

Afrykaner - hol. Afrikaner „Afrykanin, Holender osiedlony w Afryce”; 1. potomek kolonistów holenderskich, którzy osiedlili się w Afryce Południowej w XVII i XVIII w.; 2. biały mieszkaniec Afryki Południowej, zwłaszcza Republiki Południowej Afryki [USJP 2003]; członek społeczności wywodzącej się ze środowiska kolonistów holenderskich w Afryce Południowej [SJP 1998]; 1. Afrykaner - potomek kolonistów holenderskich mieszkający w Afryce Południowej, 2. afrykaner - biały mieszkaniec Afryki, zwłaszcza RPA [ISJP 2000].

Afrykanin jest więc ściśle powiązany z Afryką, miejscem nie tylko swojego zamieszkania, ale i pochodzenia. Centralne cechy omawianego leksemu to mieszkaniec (Afryki) i czarnoskóry. Warto dodać, że Afrykanin często pojawia się także jako określenie synonimiczne Murzyna.

\section{MURZYN}

Do najważniejszych leksemów należy także Murzyn. Leksem ten pochodzi prawdopodobnie od łacińskiego Maurus ‘czarny’ (ang. Negro, franc. Noir, niem. Mohr). W języku polskim jako odpowiednik osoby czarnoskórej po raz pierwszy pojawia się w XIV wieku [ESJP 2000]. Andrzej Bańkowski [ESJP 2000: 226] zauważa, że określenie to wystąpiło w obu psałterzach jako przekład łacińskiego Aethiops. Według badacza prawdopodobne jest, że określenie to stanowi zapożyczenie wędrowne ze staro-cerkiewno-słowiańskiego, typowo przekładowe słowo biblijne. Bańkowski wskazuje także leksemy innych języków, np. hiszp. i wł. moro, franc. more, czes. mour - sadza, kopeć, greckie smouros - ciemny; greckie Aitiops - ciemnolicy, o ogorzałej od słońca twarzy; a także zwraca uwagę na powiązania z określeniami „,ciemność”, ,„coś ciemnego”, odsyła do haseł: chmura, chmurzyć (się) [ESJP 2000: 135] - w XIV wieku nazwa osobowa, w 1438 r. - mroczny, czynić ciemnym (zwłaszcza o niebie), ciemny; morag [ESJP 2000: 210] - coś (zwierzę, ptak, owoc) z ciemnymi pręgami na powierzchni (sierści, skórze, piórach); moręgi - pręgowany, ciemny, ciemnoskóry; murzyć [ESJP 2000: 226] - czernić, farbować na czarno. 
Relacje z badań

Leksem Murzyn od lat budzi wiele wątpliwości wśród użytkowników języka polskiego obawiających się zarzutu niepoprawności politycznej, co ma związek z kwestiami rasowymi, politycznymi, kolonizatorskimi. Polska jednak nie miała kolonii w Afryce i większość kłopotów wiąże się raczej z tłumaczeniami Murzyna na angielski lub francuski, w których to językach nadal występują negatywnie nacechowane leksemy określające Murzynów. W języku polskim również można znaleźć wiele powiedzeń, związków frazeologicznych i określeń, które pejoratywnie wartościują mieszkańców Afryki (Por.: Murzyn zrobił swoje, murzyn może odejść [USJP 2003, WSJP 2007, SJP 1998], biały murzyn [SF PWN 2008]). W większości jednak występują one w starszych słownikach (np. Negr [ESJP 2000: 289; SJP 1958]), a współczesne nacechowanie omawianego określenia zdaje się być jednak bliższe uczuciu współczucia niż nienawiści i pogardy. Poza tym często określenia tego typu zdają się wskazywać na egzotykę Afryki, która poprzez swą odmienność i tajemniczość budzi zainteresowanie Polaków. Zagadnienie to będę jednak badać dokładniej w pracy doktorskiej, analizując konkretne teksty polskich reporterów - w tym miejscu prezentuję jedynie badany materiał słownikowy. Definicje ponumerowane od 1 do 4 to znaczenia występujące zwykle w słownikach, stanowiące główne rozumienia leksemu Murzyn: 1. człowiek należący do rasy czarnej; 2. murzyn, pot. 1. człowiek opalony na ciemny brązowy kolor; 3. ktoś, kto wykonuje pracę za kogoś, zwykle odpłatnie i bez ujawniania swego nazwiska; Szukał murzyna, który napisze mu pracę magisterską; 4. ktoś, kto ciężko pracuje, jest wyzyskiwany i źle traktowany jak niewolnik; przysłowie Murzyn zrobił swoje, murzyn może odejść - kogoś wykorzystano i odprawiono, gdy przestał być potrzebny [USJP 2003, WSJP 2007, SJP 1998]. W innych słownikach znajdujemy mniej typowe definicje, np. 1. to człowiek o bardzo ciemnej skórze, którego przodkowie wywodzą się z Afryki [ISJP 2000]; 1. Nigryczykowie abo murzyny, nazwisko, które dajemy narodom czarnym, mieszkańcom w Nigrycyi, Gwinei, Abissynii i innych pogranicznych krajach, 2. tak nazywamy ludzi czarnych, z krajów południowych pochodzących [SJP 1951].

W języku polskim od leksemu Murzyn utworzono wiele wyrazów pochodnych; ich definicje słownikowe podaję poniżej.

Murzynek -1. mały murzyński chłopiec [SJP 1998]; Murzynek Bambo w Afryce mieszka, czarna ma skórę ten nasz koleżka (Julian Tuwim) [USJP 2003], 2. murzynek - zwykle określa się tak także ciasto kakaowe i porcję mocnej czarnej kawy (reg. krak.) - wypić murzynka [USJP 2003, WSJP 2006], niegdyś także konia [SJP 1958]; Murzyniak - rzad. posp. chłopiec murzyński [SJP 1958], Murzyniątko - pot. pieszcz. małe murzyńskie dziecko [USJP 2003]; zdrobnienie od Murzynię [SJP 1958], Murzynię - małe dziecko murzyńskie [SJP 1958]. 
Murzynka - 1. kobieta należąca do rasy czarnej; 2. murzynka - odmiana truskawek o drobnych, ciemnoczerwonych owocach, a także owoc tej odmiany [USJP 2003, WSJP 2007, SJP 1998, SJP 1951, SJP 1958].

W słowniku Doroszewskiego [SJP 1958] występują także inne hasła związane z leksemem Murzyn, zwykle nacechowane negatywnie, por.:

Murzynisko - z pogardą, lekceważąco lub serdecznie o Murzynach.

murzyństwo - rzad. pogardliwie o Murzynach.

Negr, Negrzy - dziś z odcieniem pogardy, człowiek odmiany czarnej; Murzyn. Wyraz Negr rozpowszechnił się u nas zwłaszcza ostatnimi czasy, ale nieco zacieśniłsię w swym znaczeniu, przybierając odcień pewnej wzgardy [SJP 1958]. Wynotowuje go także Bańkowski jako określenie Murzyna, powołuje się także na teksty Słowackiego i leksemy z języków obcych, np. fr. negre - murzyński, hiszp. negro - czarny, łac. niger - czarny [ESJP 2000: 289].

Powyżej zaprezentowałam najważniejsze eksplikacje leksemów Afryka, Murzyn i Afrykanin wynotowane z polskich słowników, a w tym miejscu wyróżnię typy znaczeń. Współcześnie na podstawie definicji słownikowych, frazeologizmów i Korpusu Języka Polskiego PWN można wyróżnić cztery grupy. Są to:

- określenia świadczące o traktowaniu Afrykanów i Afryki neutralnie, często odnoszące się do głównej cechy mieszkańców tego kontynentu, czyli ciemnego koloru skóry lub po prostu wskazujące na coś właściwego Murzynom (1). Przykłady: czarniejszy od Murzyna, czarne buzie Murzynków [KJP PWN], kraje afrykańskie [SWJP 2003], murzyński wódz [SWJP 2003], afrykańskie drzewo (baobab), afrykańska choroba ssaków przenoszona przez muchy tse-tse (nagana, n’gana), afrykańska francuszczyzna służąca jako język międzyplemienny (Petit François) [SP 1999], Murzyńskie usta [SWJP 2003], Murzyńskie wargi [USJP 2003], wojna Afrycka [SJP 1951], kontynent afrykański [KJP PWN], afrykański upał, skwar afrykański, afrykańska temperatura - wielki skwar, bardzo wysoka temperatura [SJP 1958, SJP 1998], opalić się na murzyna - posp. opalić się na bardzo ciemny, brązowy kolor; Chciałbym, tak jak ty, opalić się na murzyna; czarny jak Murzyn - posp. bardzo opalony: Mój syn wrócił z letnich wakacji czarny jak Murzyn [WSFJP 2000]; czarnoskóry, czarnoskóra według ISJP [2000] oznacza osobę mającą czarną skórę; jest zwykle używany w książkach jako rzeczownik oznaczający Murzyna, Murzynkę [USJP 2003]; czarnoskóry, czarnoskóra - Murzyn, Murzynka [SWJP 2003, ISJP 2000]; 
- określenia przedstawiające Afrykanów (Murzynów) jako ludzi gorzej radzących sobie w życiu, czyli traktowanych ze współczuciem i wyższością (2). Przykłady: biały murzyn - posp. ktoś ciężko pracujący, wykorzystywany, źle traktowany [SF PWN 2008]; Nie daj się nabrać, oni szukają białego murzyna [WSFJP 2000]; przysłowie Murzyn zrobił swoje, murzyn może odejść [USJP 2003, WSJP 2007, SJP 1998]; murzyński niewolnik; samorząd nie będzie „,murzynem” za wszystkich pracującym [KJP PWN];

- określenia na coś, co jest wyjątkowe, ponieważ jest afrykańskie, a więc dla nas inne, ciekawe, egzotyczne (3). Przykłady: murzyńska muzyka [SWJP 2003], afrykańska restauracja, wyprawa afrykańska, afrykańskie safari, tańczyć po afrykańsku, bajkowa afrykańska sceneria [KJP PWN], afro - fryzura uformowana z mocno skręconych włosów, krzaczasto nastroszonych, szczególnie popularna wśród Murzynów [USJP 2003, SWJP 2003], gitara Murzynów (banjo) [SP 1999]. Część przykładów z grupy pierwszej może się znaleźć także w tej, w zależności od kontekstu, np.: murzyńskie wargi [USJP 2003], afrykański upał [SJP 1998];

- określenia zdecydowanie pejoratywne (4). Przykłady: ciołek afrykański z tego Władka! [KJP PWN], murzyństwo - rzad. pogardliwie o Murzynach [SJP 1958], straszyć dzieci czarnym ludem; być sto lat za Murzynami; Murzyn zrobił swoje, Murzyn może odejść - powiedzenie. Ktoś po spełnieniu swojej roli zaczyna komuś zawadzać [WSFJP 2000]; murzyństwo - rzad. pogardliwie o Murzynach [SJP 1958]; fraz. pot. wulg.: Ciemno jak w dupie u Murzyna [USJP 2003], Negr, Negrzy - dziś z odcieniem pogardy, człowiek odmiany czarnej; Murzyn [SJP 1958]; czarny towar - niewolnicy afrykańscy wystawieni na sprzedaż [SJP 1958]; czarny, czarna - w użyciu rzeczownikowym potocznie i pogardliwie Murzyn, Murzynka [USJP 2003, USJP 2009]; czarnuch - pogardliwie o Murzynie [SJP 1958, SJP 1998, ISJP 2000, USJP 2003, WSJP 2006]. Co ciekawe, w słowniku Doroszewskiego [SJP 1958] czytamy: czarnuch - 'mężczyzna, chłopiec o ciemnej cerze lub czarnych włosach’, czyli leksem ten nie jest tu utożsamiany z określeniem pejoratywnym.

Jednak nie tylko nazwy czarnoskórych mieszkańców Afryki, Murzyn czy Afrykanin, bywają negatywnie nacechowane, gdyż znajdujemy także pejoratywne powiedzenia odnoszące się do Afryki w ogóle: Jedź do Afryki prostować banany - młodz. obelż. wynoś się; odczep się; prostować banany - iron. robić coś niedorzecznego, nikomu niepotrzebnego. Siedzą w tych komitetach i prostują banany, ale żeby tak który zajął się biedakami, to już nie ma żadnego [WFSJP 2000].

Należy jednak pamiętać, że w drugiej połowie XIX wieku w europejskiej świadomości ludzkiej funkcjonowałnegatywny obraz Afryki i jej mieszkańców. Miał on usprawiedliwiać 
ekspansje i podziały kolonialne Afryki, prowadzone dla korzyści, nie w celach cywilizacyjnych. Ten uproszczony i zakłamany obraz był tak silnie utrwalany ${ }^{4}$, że pozostawia ślady do dziś. Encyklopedia Britanica z 1884 roku wyjaśniała, że Afrykanie to lud bez religii, głoszący kult przodków i wiarę w duchy [Zins H. 2001]. Podróżnicy i misjonarze głosili, że kształt głów Afrykanów jest dowodem na brak rozumu, uczuć i łagodności, a w literaturze Afrykę przedstawiano jako teren śmierci, najciemniejszy obszar, kontynent groźnych upałów, kanibalizmu, wszelkiego zła i zacofania (por.: Joyce Cary, Ethelred Lewis, William Windwood Reade, Rudyard Kipling itd.). Głównie z tych powodów także Polacy traktowali Afrykanów jak głupszych, gorszych, dzikich i wymagających misji cywilizacyjnej. Taka postawa utrzymywała się bardzo długo, a spowodowana była głównie przez niewiedzę [Zins 2001: 191].

\section{Podsumowanie}

Podsumowując, jako prototypowe cechy Afrykanina - na podstawie współczesnych słowników - wyróżnić należy miejsce jego zamieszkania (Afryka), a także kolor skóry. Z kolei Murzyna - czarną skórę, rdzenność - miejsce pochodzenia i życia, cechy fizyczne (czarne włosy, fryzura na afro, duże i wywinięte wargi lub usta). W tym miejscu należy także dodać, że w pewnym stopniu leksem Murzyn nadal może być nacechowany negatywnie (pogarda), a Afrykanin jest wolny od tego typu powiązań. Cechy (atrybuty) przypisywane Afryce w ogóle są zazwyczaj wyrażone przez określenia wartościujące i wiążą się z jej mieszkańcami.

Z powyższych haseł słownikowych wynika, że cechy definicyjne, prototypowe w polu omawianych leksemów związanych z Afryką, to: część (świata, Afryki), rdzenni mieszkańcy i ich poczucie odmienności (Murzyni), kolor skóry jej mieszkańców (ciemny, czarny), czerń (jako ciemny kolor, ale także jako nośnik nacechowań negatywnych), brak poczucia własnej wartości. Należy także dodać, że wiele użyć negatywnych funkcjonuje w języku polskim na zasadzie przenośni, nie mają one obrażać Afrykanów, lecz raczej danego odbiorcę (Polaka, Europejczyka, człowieka odmiany białej, Amerykanina). Nie jest tu istotny kolor skóry ani narodowość, lecz raczej pewne predyspozycje, cechy charakteru, brak poczucia własnej wartości, np. być Murzynem, być od czarnej roboty, czyli pracować za darmo lub za marne wynagrodzenie; niewdzięczna czarna robota; samorząd nie będzie „murzynem” za wszystkich pracującym, tak jak nie będzie osiołkiem [KJP PWN]; Murzyn zrobił swoje, murzyn może odejść [USJP 2003, WSJP 2007, SJP 1998]. Powyższe dane planuję

\footnotetext{
${ }^{4}$ Głównie przez działaczy politycznych, misjonarzy i pisarzy (np. Rudyard Kipling).
} 
Relacje z badań

skonfrontować głównie z wybranymi pisanymi reportażami polskich autorów, ale także z materiałem pozyskanym ze słowników i korpusu języka suahili. Analiza tego materiału i porównanie w celu wydobycia podobieństw i różnic stanowią główny cel mojej pracy. Następnym etapem prowadzonych przeze mnie badań będzie wyodrębnienie poszczególnych domen dotyczących świata człowieka (Afrykanina) i analiza wybranych polskich reportaży (m.in. teksty Olgi Stanisławskiej, Bogdana Szczygła, Wojciecha Tochmana).

\section{Bibliografia}

Bartmiński Jerzy, Anusiewicz Janusz, 1988, Język a kultura, t. 1, Wrocław: Wiedza o Kulturze. Bartmiński Jerzy, red., 1990, Językowy obraz świata, Lublin: Wydawnictwo Uniwersytetu Marii Curie-Skłodowskiej.

Bartmiński Jerzy, 2006, Językowe podstawy obrazu świata, Lublin: Wydawnictwo Uniwersytetu Marii Curie-Skłodowskiej.

Lakoff George, Johnson Mark, 2010, Metafory w naszym życiu, Warszawa: PIW.

Markowski Andrzej, 1990, Leksyka wspólna różnym odmianom polszczyzny, Warszawa: Wydawnictwa Uniwersytetu Warszawskiego.

Niewiara Aleksandra, 2000, Wyobrażenia o narodach w pamiętnikach i dziennikach z XVI-XIX wieku, Katowice: Wydawnictwo Uniwersytetu Śląskiego.

Rembiszewska Dorota, 2005, Słownictwo tematyczne w opracowaniach leksykograficznych, „Poradnik Językowy”, nr 11, s. 37-52.

Szyjewski Andrzej, 2005, Religie Czarnej Afryki, Kraków: WAM.

Witek Halina, 2009, Wizerunek obcego. Kultury afrykańskie w relacjach Henryka Sienkiewicza, Mariana Brandysa i Marcina Kydryńskiego, Warszawa: Trio.

Wojtak Maria, 2004, Gatunki prasowe, Lublin: Wydawnictwo Uniwersytetu Marii Curie-Skłodowskiej.

Wolny Kazimierz, 1996, Reportaż - jak go napisać?, Rzeszów: Wydawnictwo Oświatowe Fosze. Wysocka Aneta, 2002, Językowy obraz Afrykanina, ,Etnolingwistyka”, nr 14, s. 175-196.

Zins Henryk, 2001, Afryka i Europa. Od piramid egipskich do Polaków w Afryce Wschodniej, [seria:] Dzieje Orientu, Warszawa: Wydawnictwo Akademickie Dialog.

\section{Słowniki, korpusy}

ESJP 2000 - Bańkowski Andrzej, red., 2000, Etymologiczny słownik języka polskiego, Warszawa: PWN.

SEJP 1927 - Brückner Aleksander, red., Słownik etymologiczny języka polskiego, Kraków: Wiedza Powszechna. 
NSEJP 2003 - Długosz-Kurczabowa Krystyna, red., 2003, Nowy słownik etymologiczny języka polskiego,Warszawa: PWN.

SWJP 2003 - Dunaj Bogusław, red., 2003, Słownik współczesnego języka polskiego, Kraków: SMS. SF PWN 2008 - Sobol Elżbieta, oprac., 2008, Słownik frazeologiczny PWN z Bralczykiem, Warszawa: PWN.

WSJP 2006 - Sobol Elżbieta, red., 2006, Wielki słownik języka polskiego, Warszawa: Świat Książki.

SJP 1998 - Szymczak Mieczysław, red., 1998, Słownik języka polskiego, Warszawa: PWN.

SJP 1958 - Doroszewski Witold, red., 1958, Słownik języka polskiego, Warszawa: PWN.

USJP 2009 - Grzenia Jan, red., 2009, Uniwersalny słownik języka polskiego, Katowice, Videograf Edukacja.

WSJP 2007 - Dunaj Bogusław, red., 2007, Współczesny słownik języka polskiego, Warszawa: Langenscheidt Polska.

ISJP 2000 - Bańko Mirosław, red., 2000, Inny słownik języka polskiego, Warszawa: PWN.

SJP 1951 - Linde Samuel Bogumił, 1951, Słownik języka polskiego, Warszawa: PiW.

KJP PWN - Korpus Języka Polskiego PWN.

SP 1999 - Kopaliński Władysław, red., 1999, Słownik przypomnień, Warszawa, Rytm.

USJP 2003 - Dubisz Stanisław, red., 2003, Uniwersalny słownik języka polskiego, Warszawa: PWN. 


\section{Comparison of the linguistic image of Africa in a specific Polish dictionary}

This project constitutes the main part of my doctoral thesis carried out under the supervision of Prof. Zbigniew Greń at the Institute of Slavic Studies of the Polish Academy of Sciences. In order to conduct comparative research and to analyze the differences between lexemes in Polish and Swahili, I have chosen methodology connected within a course of cognitive research, namely the linguistic image of the world.

As part of the project I would like to look into and describe the linguistic image of Africa in specific Polish reportages. In addition, and in order to show the differences in the ways of conceptualisation of the reality by representatives of other cultures, I am planning to visit Tanzania to do more research.

This article contains the linguistic image of Africa in a specific Polish dictionary. I have analysed the lexemes: Africa, African and Negro to show the dissimilarities.

\section{Key Words:}

Africa, African, Negro, linguistic image of the world, reportage

\section{Słowa kluczowe:}

Afryka, Afrykanin, Murzyn, językowy obraz świata, reportaż 